\title{
Natural killer cell and islet killer cell activities in Type 1 (insulin-dependent) diabetes
}

\author{
K. Negishi ${ }^{1}$, N. Waldeck ${ }^{1}$, G. Chandy ${ }^{1}$, B. Buckingham ${ }^{3}$, A. Kershnar ${ }^{3}$, L. Fisher ${ }^{4}$, S. Gupta ${ }^{1}$ and M.A. Charles ${ }^{1,2}$ \\ Departments of ${ }^{1}$ Medicine and ${ }^{2}$ Physiology, School of Medicine, University of California, Irvine, and Departments of Pediatrics, \\ ${ }^{3}$ Children's Hospital of Orange County, Orange, and ${ }^{4}$ City of Hope Medical Center, Duarte, California, USA
}

\begin{abstract}
Summary. Peripheral blood mononuclear cells from 20 Type 1 (insulin-dependent) diabetic patients were examined for natural killer cell activity using the $\mathrm{K} 562$ cell line as ${ }^{51} \mathrm{Cr}$ labeled targets. Mean natural killer cell cytotoxicity mediated by enriched non-T cells from patients $(37 \pm 4.0 \%)$ was lower $(p<$ $0.03)$ than in controls $(56 \pm 3.7 \%)$. Specificity was evaluated by examining other patient subgroups. Mean non-T cell mediated natural killer cell activity in Type 2 (non-insulin-dependent) diabetic patients and Type 1 patients with long term disease was $65 \pm 5.4 \%$ and $62 \pm 4.8 \%$ respectively $(p<0.003$ vs new onset Type 1 patients). Longitudinal studies of new onset Type 1 patients during the remission (honeymoon) phase revealed persistently impaired natural killer cell activity in 3 of 4 patients. In 30 new onset and 11 remission Type 1 diabetic
\end{abstract}

patients, mean non- $T$ cell-mediated cytotoxicity was also measured using dispersed ${ }^{51} \mathrm{Cr}$ labeled islet target cells. Mean islet cytotoxicity mediated by cells from new onset patients was $34 \pm 2.4 \%$, whereas in non-diabetic control subjects mean cytotoxicity was $25 \pm 1.8 \%(p<0.005)$. During remission, islet cytotoxicity remained at similar or elevated levels in most patients. In patients evaluated simultaneously for K562 and islet cell cytotoxicity, natural killer cell activity was decreased, whereas islet killing was increased. These results suggest a dichotomy in natural killer cell and islet killer cell activities in new onset Type 1 diabetes that could have an important role in the pathogenesis of Type diabetes.

Key words: Natural killer cells, islet cytotoxicity.
Immune mechanisms, genetic susceptibility and environmental factors (e.g. viruses) are all implicated in the pathogenesis of Type 1 (insulin-dependent) diabetes [1]. Immune cytotoxic studies have focused upon antibodymediated mechanisms of islet destruction [2-4]. We have previously reported specifically increased cell-mediated cytotoxicity against islet target cells in Type 1 diabetes [4]. One potential cell-mediated killing mechanism for islet cell destruction could be related to natural killer (NK) cells. NK cells are reported to have a significant role in resistance to viral infections [5]. It is documented in animals [6] and suggested in humans [7] that viruses can cause pancreatic islet $\mathrm{B}$ cell destruction. Thus, it is conceivable that NK cells could be directly cytotoxic to islet cells, or that NK cell defects could result in susceptibility to viral infections, which in turn could play an important role in the pathogenesis of Type 1 diabetes. Further, other diseases thought to be autoimmune in nature have been associated with decreased NK cell populations or decreased K562 killing $[8,9]$.

We have recently reported preliminary results that Type 1 diabetes is associated with a quantitative and functional deficiency of circulating NK cells using Leu 7 monoclonal antibody and K562 target cell cytotoxicity $[10,11]$. Preliminary confirmation of these data by Herald et al. [12] has also appeared. Since a dissociation between phenotypically defined NK cells and function- al abnormalities of NK cells has been described in other disorders [13], we compared the percent of circulating HNK-1 + mononuclear cells and NK cell cytotoxic function in Type 1 diabetes using target cells from the K562 cell line. We also compared NK killing activity with cell-mediated islet cytotoxicity in Type 1 diabetic patients.

\section{Subjects and methods}

\section{Subjects}

New onset Type 1 diabetic patients were evaluated for islet and K562 cell cytotoxicity. Each patient and control subject understood and signed approved university consent forms prior to their participation in this project. Patient and control group age, sex and disease duration are described in Table 1. The diagnostic criteria of Type 1 and 2 diabetes have been previously described [14]. The remission phase of diabetes was defined as an insulin requirement of $<0.5 \mathrm{U} / \mathrm{kg}$ per day, with normal fasting blood glucose levels of $1 \%$ or less urine testing for glucose occurring for longer than one week. Type 2 diabetic control subjects all used insulin treatment. Normal subjects had no known immune abnormalities, normal fasting blood glucose levels and no family history of diabetes. For K562 studies, the new onset Type 1 patients and non-diabetic control group had similar numbers of males and females, since sex, but not age, is reported to be related to K562 cytotoxicity [15]. Age- and sex-matching for islet cell cytotoxicity appears relatively insignificant, since diabetes-related cytotoxicity is elevated whether the patients are matched [4] or not (this study). Each subject and patient was examined on one occasion, with the exception 
Table 1

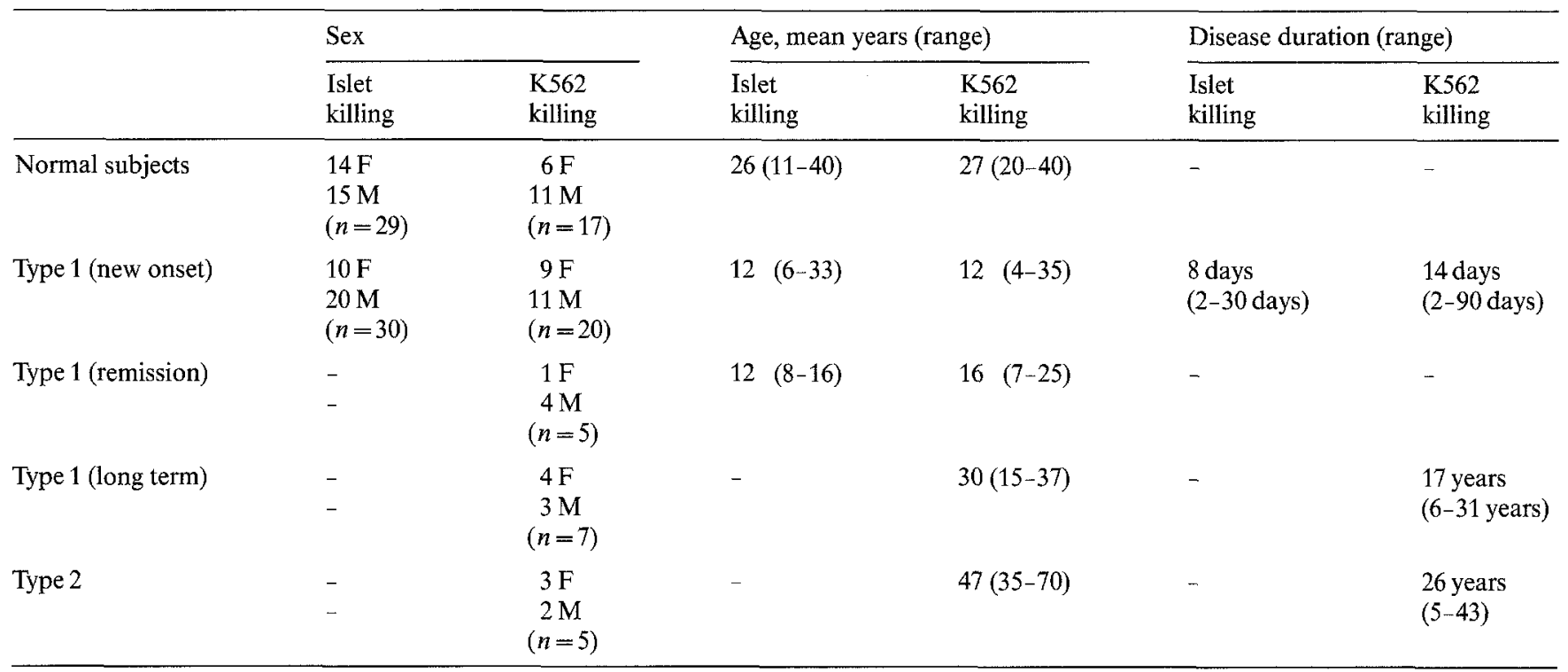

of patients studied longitudinally during the remission phase. Not all patients were examined for all parameters, but all studies performed are presented.

\section{Effector cell preparation}

Heparinized venous blood $(200 \mathrm{U} / \mathrm{ml}$, preservative-free heparin; Gibco Laboratories, Grand Island, NY, USA) was used in all control subjects and diabetic patients. Enriched mononuclear cells were isolated using Ficoll-Hypaque (Pharmacia Fine Chemicals, Piscataway, NJ, USA) as described elsewhere [16]. Mononuclear cell preparations contained $60-80 \%$ T lymphocytes, $10 \%$ monocytes, $12-15 \%$ B lymphocytes and 5-8\% null cells. Cells harvested from the interface were washed three times in $\mathrm{Ca}^{++}$and $\mathrm{Mg}^{++}$free Hanks' balanced salt solution (HBSS, Gibco). Non-T mononuclear cells were enriched by depletion of $\mathrm{T}$ cells using 1\% 2-aminoethyl isothiouronium hydrobromide-treated sheep erythrocytes [17]. T lymphocyte rosettes were separated from non-T cells using Ficoll-Hypaque centrifugation. Non-T mononuclear cells obtained from the interface were washed three times with HBSS and resuspended in the appropriate culture medium. The non-T enriched mononuclear cell preparations contained $66 \%$ B cells, $20-25 \%$ monocytes, $15-20 \%$ null cells, and less than $5 \% \mathrm{~T}$ cells. Effector cell viability was greater than $95 \%$ by the trypan blue dye exclusion test.

\section{Target cell preparation}

The human myeloid $\mathrm{K} 562$ cell line was carried in culture as previously described [18]. K562 cells were grown in suspension culture using RPMI 1640 (Whittaker M.A. Bioproducts, Walkersville, MD, USA) and $10 \%$ fetal calf serum, $25 \mathrm{~mol} / 1$ Hepes buffer, penicillin and streptomycin. $2 \times 10^{6} \mathrm{~K} 562$ cells were labeled with ${ }^{51} \mathrm{Cr}$ (200 ul sodium chromate, $1 \mathrm{mCi} / \mathrm{ml}$, New England Nuclear, Cambridge, MA, USA) at $37^{\circ} \mathrm{C}$ for $60 \mathrm{~min}$. After washing three times with culture medium, the labeled K562 cells were resuspended in the culture medium and adjusted to $1 \times 10^{5}$ cells $/ \mathrm{ml}$. Inbred Lewis rat islet cells were also used as target cells. Rat islets were isolated using collagenase, then were purified by centrifugation and visual selection as described previously [19]. Dispersed rat islet cells were prepared as described previously [3]. Purified intact islets were incubated at $37^{\circ}$ for $1-2$ days in Dulbecco's modified Eagles Medium (DMEM) and 10\% fetal calf serum in 5\% $\mathrm{CO}_{2}$ and $95 \%$ humidified atmosphrere. Individual intact islets were dispersed into a single cell suspension by incubation in $200 \mu \mathrm{g} / \mathrm{ml}$ DNAase (Sigma, St. Louis, MO, USA) in Swim's low calcium me- dium (Gibco) containing $1 \mathrm{mmol} / \mathrm{l}$ EGTA (Sigma) and $1 \%$ bovine serum albumin (Miles Laboratories, Kankakee, IL, USA). The dispersed cells were washed, placed in $200 \mu \mathrm{L}$ DMEM with $10 \%$ fetal calf serum and incubated with ${ }^{51} \mathrm{Cr}(50 \mu \mathrm{l}$ sodium chromate, $1 \mathrm{mCi} / \mathrm{ml}$, New England Nuclear, Cambridge, MA, USA) at $37^{\circ}$ for $30 \mathrm{~min}$. After washing, ${ }^{51} \mathrm{Cr}$-labeled islet cells were used as target cells. Viability for both K562 and islet cells was greater than $90 \%$ by trypan blue exclusion.

\section{K562 NK cell assay}

Cytotoxicity against K.562 target cells was performed in standard Vshaped microplates (Nunc, Kamstrups, Denmark) in a total volume of $200 \mu \mathrm{l}$ as previously described [20]. $1 \times 10^{4}$ target cells were incubated with variable numbers of effector cells for $4 \mathrm{~h}$ at $37^{\circ}$ under $5 \% \mathrm{CO}_{2}$ and $95 \%$ humidified atmosphere. After incubation, $100 \mu$ of supernatant was collected, the amount of ${ }^{51} \mathrm{Cr}$ release was determined and the percent specific cytotoxicity from triplicate determinations was calculated as previously described [3] as follows:

mean experimental cpm - mean spontaneous cpm

mean maximum cpm - mean spontaneous cpm

100

Mean spontaneous release determined from experiments $(n=20)$ after incubation of target cells was $9.4 \%(454 \pm 16 \mathrm{cpm})$, and maximal release using $20 \mu 1$ of $10 \%$ Triton $X-100$ was $96 \%(4819 \pm 172 \mathrm{cpm})$.

\section{Islet cell cytotoxicity assay}

This assay was performed as described previously in detail [3, 4]. Triplicate $400 \mu \mathrm{l}$ polyethylene tubes contained MEM, $10 \%$ fetal calf serum, $10^{4}{ }^{51} \mathrm{Cr}$-labeled islet targe cells and variable quantities of effector cells. Incubations were performed for $8 \mathrm{~h}$ at $37^{\circ}$ in $5 \% \mathrm{CO}_{2}$ and $95 \%$ humidified atmosphere. After incubation, the tubes were mixed, centrifuged at $11600 \times \mathrm{G}$ for $2 \mathrm{~min}$, and supernatants and pellets were assessed for radioactivity. Spontaneous release was 21\% (528 \pm $23 \mathrm{cpm}$ ) from tubes containing no added mononuclear cells. Maximal release using $1 \%$ Triton X-100 treated cells was $96 \%$ (2507 $\pm 126 \mathrm{cpm})$. Specific cytotoxicity was calculated as described above for K562 target cells. Interassay variation was examined by repeated assays in one normal subject. Mean islet cytotoxicity was $25 \pm 3.8 \%$ at a $1: 20$ target: effector ratio $(n=7)$. The islet assay was evaluated for islet target cell specificity as previously described [4], where rat conconavalin-A stimulated lymphoblast and rat macrophage target cells were not lyzed to the extent of islet cells. 


\section{Monoclonal antibody $\left(\right.$ Leu $\left.7^{+}\right)$defined cells}

The mononuclear cells were incubated with appropriate dilutions of fluorescein conjugated anti-Leu 7 monoclonal antibody (Bectin-Dickinson, Mountainside, Calif., USA) and Leu $7^{+}$cells were enumerated with FACS analyzer (Bectin-Dickinson) as previously described [10].

\section{Statistical analysis}

All data are presented as mean $\pm \mathrm{SEM}$, and $p$ values were determined using the Student's unpaired t-test unless otherwise stated. The Pearson correlation coefficient method was used.

\section{Results}

\section{K562 cytotoxicity}

Natural killer (NK) cell activity of peripheral blood mononuclear cells from new onset Type 1 diabetic patients and non-diabetic control subjects was evaluated using K562 target cells. Mean cytotoxicity mediated by enriched mononuclear cells at 1:10 and 1:50 target: effector ratios were lower in diabetic patients than in control subjects; these data have been previously published [11]. Mean enriched non-T cell killing of K562 cells was lower in new onset Type 1 patients $(1: 10,22 \pm 3.2 \% ; 1$ : $50,37 \pm 4.0 \%)$ than in control subjects $(1: 10,37 \pm 4.1 \%$ $(p<0.03) ; 1: 50,56 \pm 3.7 \%(p<0.03)$. To assess specificity of NK cell activity to new onset Type 1 patients, NK activity was also measured in 2 other patient subtypes (Fig. 1). Mean NK activity in long-term Type 1 patients was $24 \pm 2.9 \%$ at a target: effector ratio of $1: 10(\mathrm{p}=\mathrm{NS}$ vs new onset) and $62 \pm 4.8 \%$ at $1: 50$ ( $p<0.03$ vs new onset). Mean NK activity in Type 2 diabetic patients was $36 \pm 5.4 \%$ at a target: effector ratio of $1: 10(p<0.05$ vs new onset) and $65 \pm 5.4 \%$ at $1: 50(p<0.03$ vs new onset). In new onset Type 1 patients who were longitudinally followed into the remission (honeymoon) phase (Fig. 1), NK activity remained impaired in 3 of the 4 patients ( $p=\mathrm{NS}$ vs new onset).

Mean levels of circulating mononuclear cells expressing reactivity to Leu 7 were lower $(9.0 \pm 0.9 \%)$ in new onset Type 1 patients than in non-diabetic controls $(19 \pm 1.5 \%, p<0.001$, Fig. 2$)$, which was also true for enriched non-T cells $(14 \pm 2.2 \%$ vs $22 \pm 1.8 \%$ in controls, $p<0.006$, Fig. 3).

\section{Islet cytotoxicity}

We have previously reported in preliminary studies that islet cytotoxicity is increased using enriched mononuclear cells or enriched non-T cells from new onset Type 1 diabetic patients [4]. The current study confirms increased islet cytotoxicity by non-T mononuclear cell preparations derived from 30 new onset Type 1 diabetic patients when compared to 29 non-diabetic control subjects (Fig. 4). As shown in Figure 5, islet cytotoxicity by non- $T$ cells during the remission phase of diabetes in 11 patients was decreased toward normal values in 4 , relatively unchanged in 4 and increased in 3 patients.

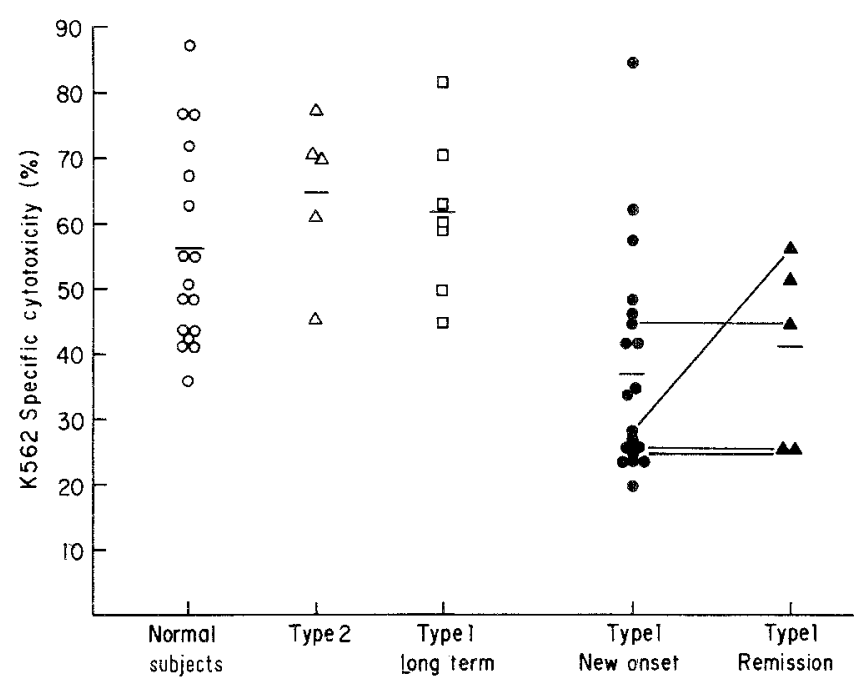

Fig. 1. Individual data for enriched non-T cell mediated K562 cytotoxicity is shown for non-diabetic normal subjects (normal subjects, open circles), long-term Type 2 diabetic patients (Type 2, open triangles), long-term Type 1 diabetic patients (Type 1 long term, open squares), new onset Type 1 patients (Type 1 new onset, closed circles), and Type 1 diabetic patients during remission (Type 1 remission, closed triangles). Horizontal bars indicate mean K562 specific cytotoxicity, and lines connecting closed circles with closed triangles indicate longitudinal data derived from one patient. Mean specific cytotoxicity derived from new onset Type 1 patients is lower than from non-diabetic normal subjects $(p<0.03)$, Type 2 patients $(p<0.03)$, and long-term Type 1 patients $(p<0.03)$. Mean specific cytotoxicity in remission patients was not different from new onset Type 1 patients $(p=\mathrm{NS})$. All data shown are at a target: effector ratio of $1: 50$

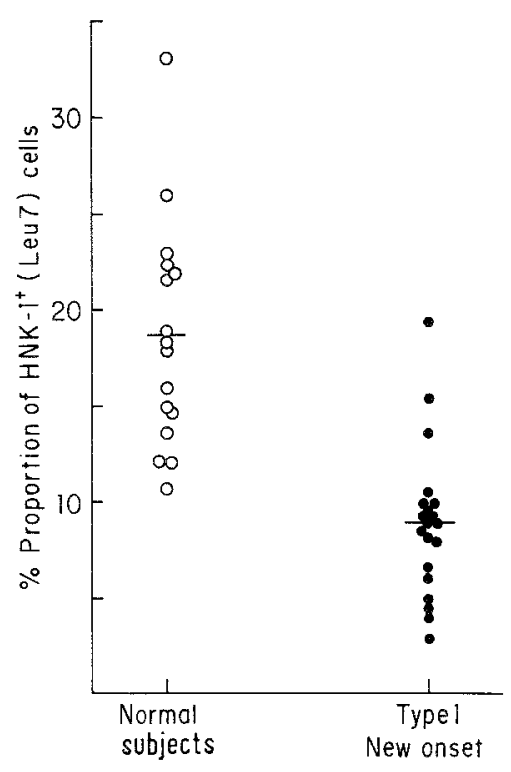

Fig. 2. The percent of circulating peripheral mononuclear cells reactive with HNK-1 (Leu 7) monoclonal antibody is indicated for each non-diabetic normal subject (normal subjects, open circles) and each new onset Type 1 diabetic patient (Type 1 new onset, closed circles). Horizontal bars indicate mean percent proportion of HNK-1 positive cells which is lower in new onset Type 1 patients than in normal subjects $(p<0.001)$ 


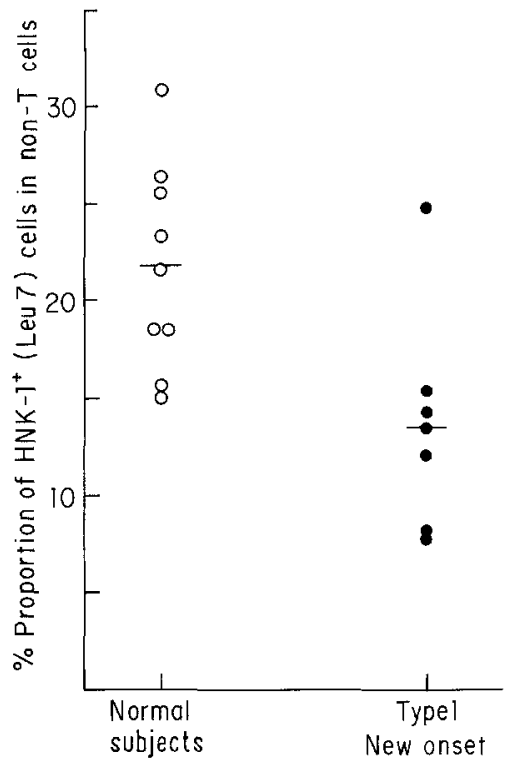

Fig. 3. The percent proportion of HNK-1 (Leu 7) positive cells in non- $T$ cells enriched from circulating peripheral mononuclear cells derived from non-diabetic normal subjects (normal subjects, open circles) and new onset Type 1 diabetic patients (Type 1 new onset, closed circles) is shown. Horizontal bars indicate the mean percent proportion of HNK-1 positive cells, which is lower in new onset Type 1 patients than in normal subjects $(p<0.006)$

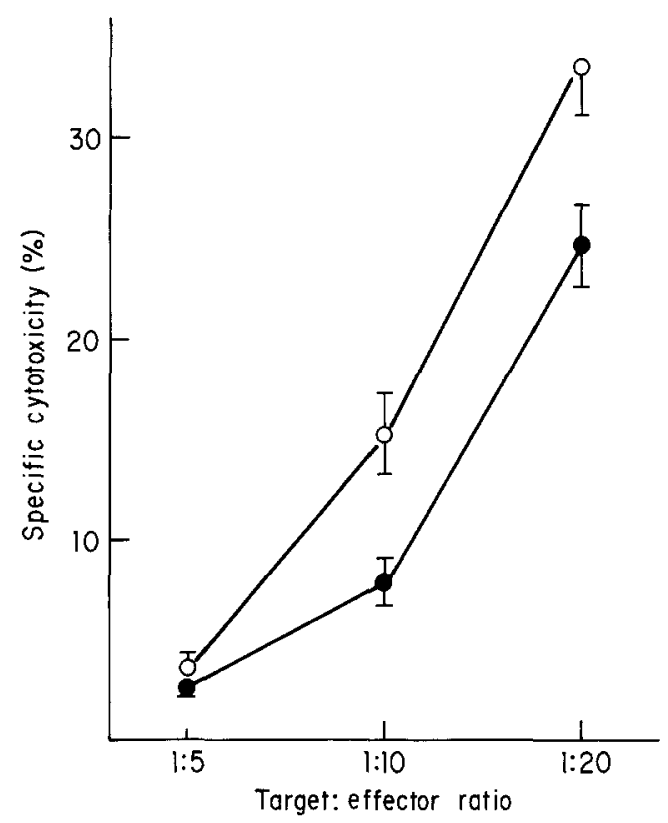

Fig.4. Mean enriched non-T cell mediated islet cell cytotoxicity is shown for 29 non-diabetic control subjects (open circles) and 30 new onset Type 1 diabetic patients (closed circles). The bars indicate standard error of the mean at the target: effector ratios $1: 5(p=$ NS), $1: 10$ $(p<0.002)$ and $1: 20(p<0.005)$

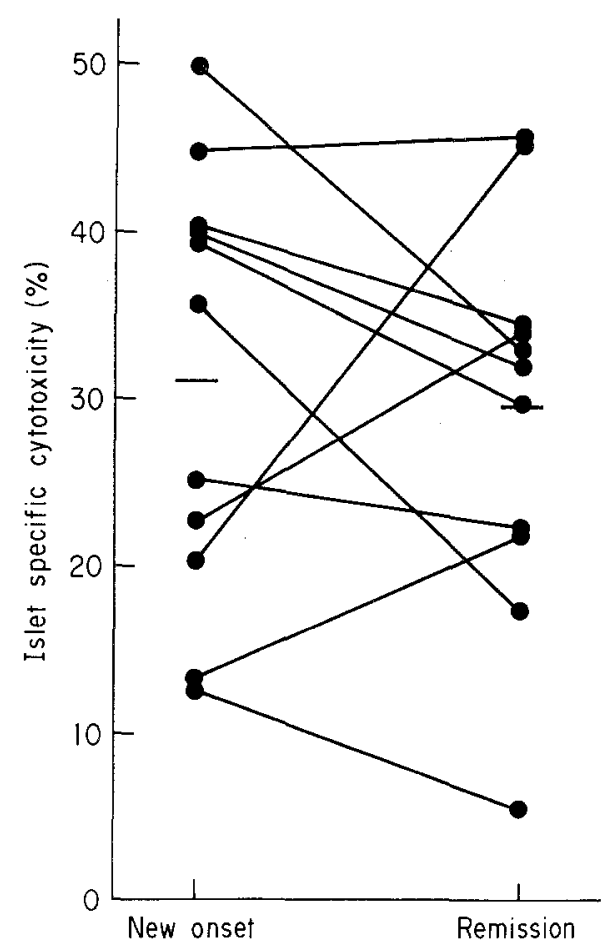

Fig. 5. Enriched non-T cell mediated islet cell cytotoxicity in new onset Type 1 diabetic patients (new onset) and the same Type 1 diabetic patient during the remission phase (remission) is shown. Mean cytotoxicity levels illustrated by horizontal bars are not statistically different $(p=$ NS). The data shown is at a target: effector ratio of $1: 20$

The mean remission level of islet cytotoxicity was not significantly different from the mean new onset cytotoxicity levels.

\section{Comparisons of cellular killing using $K 562$ and islet target cells}

As described above for all of the cross-sectionally evaluated new onset Type 1 patients and the non-diabetic control group, Type 1 patients show impaired killing against K562 cells and enhanced killing against islet target cells. To determine whether more direct relationships exist between K562 and islet cytotoxicity in Type 1 diabetes, seventeen new onset Type 1 patients were simultaneously evaluated for both K562 and islet non-T lymphocyte-mediated cellular cytotoxicity. Mean islet cytotoxicity at a target: effector ratio of 1:20 was increased in these patients to $34 \pm 3.3 \%$ compared to $25 \pm 1.8 \%$ in 29 control subjects $(p<0.01)$, whereas NK activity at a $1: 50$ target effector ratio was reduced to $37: 3.0 \%$ versus $56 \pm 3.7 \%$ in the non-diabetic controls $(p<0.002)$. To emphasize the discordant cytotoxicity of these two target cells, data from each new onset Type 1 patient is illustrated as the percent stimulation above the mean control level for islet target cells and the percent inhibition below the mean control level for K562 cells (Fig.6). In these simultaneously studied new onset patients, a significant correlation was observed between 


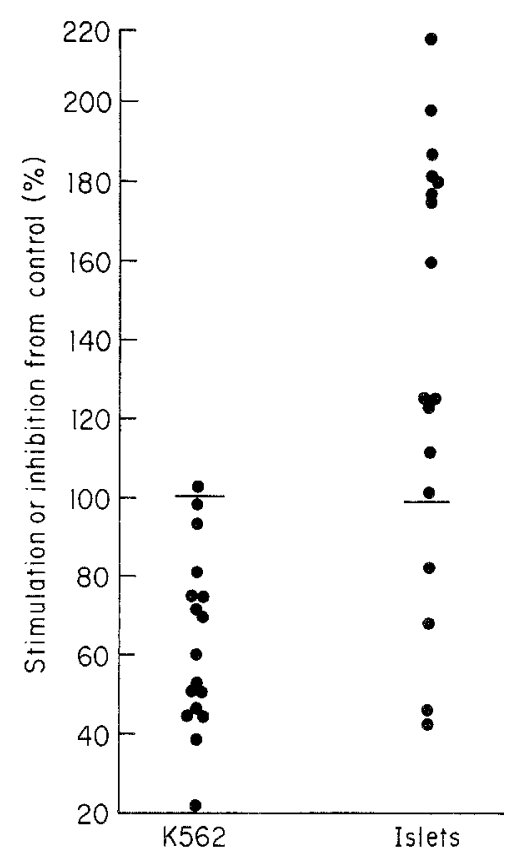

Fig. 6. Individual cytotoxicity data derived from new onset Type 1 diabetic patients is shown for K562 target cells (K562) and islet target cells (Islets). Mean cytotoxicity from non-diabetic control subjects is set at $100 \%$ (horizontal bars) on the vertical axis. Data points above bars indicate stimulation above mean control cytotoxicity, whereas points below bars reflect inhibition below mean control cytotoxicity levels

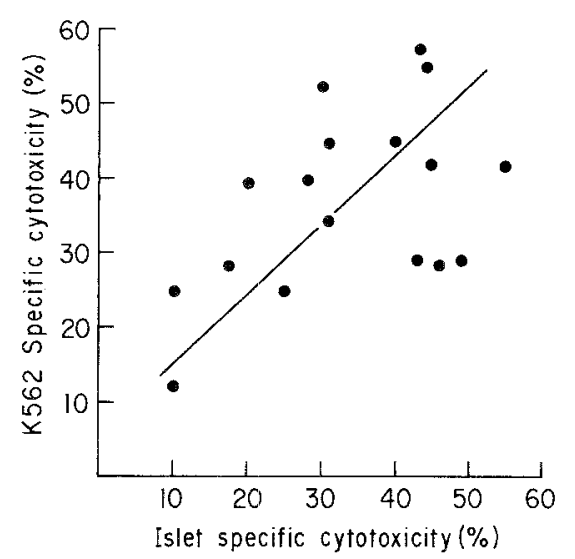

Fig.7. Closed circles represent individual K562 specific cytotoxicity at a target: effector ratio of 1:50 compared to the same new onset Type 1 patient for islet specific cytotoxicity at a target: effector ratio $1: 20$. A positive correlation of K.562 and islet cytotoxicity is shown $(r=0.47, p<0.04)$

K562 and islet target cell killing $(r=0.47, p=0.04$, Fig. 7). Thus, patients with the higher K562 cytotoxicity also showed the higher islet cytotoxicity even though absolute levels of cytotoxicity for K562 cells was low and for islet cells was high. No significant correlation was observed between circulating Leu $7^{+}$cells and islet killing $(r=0.03, p=\mathrm{NS}, n=7)$.

\section{Discussion}

This study indicates that NK cell activity against K562 target cells is decreased in new onset Type 1 diabetic patients, whereas islet cell killing is increased. These data are concordant with our previous preliminary results, in which we describe a decrease in the percent of monoclonal antibody-defined circulating NK cells, a decrease in NK functional activity and enhanced islet cell cytotoxicity in new onset Type 1 diabetes $[4,10,11]$. In this report we expand our preliminary results in evaluating functional NK activity in new onset Type 1 patients using K562 target cells. We also describe the specificity for impaired NK activity to new onset patients, and we compare K562 and islet cytotoxicity in simultaneously evaluated patients.

It is known that enriched $T$ cells also manifest cytotoxicity to K562 cells. Thus, the non-T enriched mononuclear cell populations used in this study do not define all K562 killing activity. Our observations of decreased circulating Leu $7^{+}$NK cells are important since these data, combined with the killing data, imply a low level of NK cells using two different methods.

Specificity of the NK activity impairment to new onset Type 1 patients is documented by the data in Figure 2, which shows that non-diabetic subjects, long term Type 1 and Type 2 diabetic patients manifest a similar range of NK activity. Disease activity in Type 1 patients was not associated with a change in the impairment of NK function in the 3 of 4 patients assessed by longitudinal evaluation of patients during the new onset and remission periods. Non-T cell-mediated islet cytotoxicity was also unrelated to clinical disease activity in 7 of the 11 patients longitudinally evaluated during the new onset and remission periods. Protein-calorie malnutrition, which is reversible after refeeding, has been associated with impaired NK function [21]. Thus, the potential for starvation related to new onset diabetes as a cause of impaired NK function seems unlikely, since the NK and islet functional defects were not altered toward normal levels during the remission phase when patients had normalized their metabolic control and gained weight.

It appears that decreased K562 NK cell activity is a secondary manifestation of new onset Type 1 diabetes, since the defect is not demonstrable in chronic Type 1 patients. Studies of pre-clinical, islet cell antibody-positive subjects should provide more information regarding the onset of the NK impairment. If the decrease in K562 cell killing also occurs during the pre-clinical phase, this could provide an explanation for the viral infection susceptibility which is thought to have a major role in the pathogenesis of Type 1 diabetes [1].

The decreased levels of circulating Leu $7^{+}$NK cells and decreased K562 killing in diabetes could be due to several factors. One possibility is that interferon production is either deficient in Type 1 diabetes or that NK cell sensitivity to interferon is reduced. Interferon is 
known to enhance NK cell function and recruit pre-NK cells into active NK cells [22]. A second possibility is that deficient IL-2 production, recently reported in Type 1 diabetes, could result in decreased interferon production and thus NK function [22, 23]. Recently IL-3 has also been shown to enhance NK activity [24]. Finally, prostaglandins and immune complexes have been shown to inhibit NK cell function [25]. These substances have also been reported to be elevated in the circulation in Type 1 diabetes $[26,27]$.

In new onset Type 1 diabetes, when K562 NK cell activity is low, islet cytotoxicity is high, suggesting that the effector cell specificity or cell type killing each of these two target cells is different. The effector cell specificity hypothesis (i.e. one cell type killing both target cells) is supported by the correlation between K562 and islet cell killing, where more K562 killing activity is associated with more islet killing activity. Thus, the elevated islet cell cytotoxicity in Type 1 patients suggests specificity to islets, whereas the impaired K562 cytotoxicity suggests decreased specificity.

New onset Type 1 diabetes is associated with multiple cellular immune defects. We have now associated NK quantitative and functional defects to diabetes, and have emphasized the discordance for non-T cell-mediated enhanced islet cell killing and impaired NK activity.

Acknowledgements. This study was in part funded by grants from the American Diabetes Association, Southern California Affiliate and the USPHS (AM 33167). The authors thank Ms. S. Burns and Ms. L. Walter for preparing the manuscript.

\section{References}

1. Bajaj M, Barker CF, Brown DM, Chen PY, Chinn PL, Cudworth AG, Fernandes G, Grammer LC, Gupta S, Handwerger BS, Huber SA, Jansen FK, Kahn CR, Young TK, Kumar D, Lernmark A, MacPherson BR, Mann D, Miller ME, Moody CE Jr, Moorow CE, Muntefering H, Naji A, Nerup J, Patterson R, Pitts JE, Rosenthal AS, Scott J, Sutherland DE, Wolf E (1984) Immunology of clinical and experimental diabetes, 1st edn (ed Gupta S). Plenum Press, New York

2. Rabinovich A, MacKay P, Ludvigsson J, Lernmark A (1983) Prospective analysis of islet cell cytotoxic antibodies in insulin-dependent diabetic children: Transient effects of plasmapheresis. Diabetes 33: 224-228

3. Charles MA, Suzuki M, Slater L, Waldeck N, Ong K (1983) Immune islet killing mechanisms associated with insulin-dependent diabetes: Three rabbit antibody-mediated islet cell cytotoxicity models. Diabetologia 25:348-354

4. Charles MA, Suzuki M, Waldeck N, Dodson LE, Slater L, Ong K, Kershnar A, Buckingham B, Golden M (1983) Immune islet killing mechanisms associated with insulin-dependent diabetes: In vitro expression of cellular and antibody-mediated islet cell cytotoxicity in humans. J Immunol 130: 1189-1194

5. Herberman RB, Ortaldo JR (1981) Natural killer cells: their role in defenses against disease. Science 214: 24-30

6. Craighead JE, McLane MF (1978) Diabetes mellitus induction in mice by encephalomyocarditis virus. Science 162: 913-914

7. Yoon JW, Austin M, Onodera T, Notkins A (1979) Virus-induced diabetes mellitus. Isolation of a virus from the pancreas of a child with diabetic ketoacidosis. N Engl J Med 300: 1173-1179

8. Iwatani Y, Amino N, Kabutomori O, Mori H, Tamaki H, Motoi S, Izumiguchi Y, Mivai K (1984) Decrease of peripheral large granu- lar lymphocytes in Graves' disease. Clin Exp Immunol 55: $239-244$

9. Auer IO, Ziemer, Sommer H (1980) Immune states in Crohn's disease. V. Decreased in vitro natural killer cell activity in peripheral blood. Clin Exp Immunol 42: 41-49

10. Chandy KG, Charles MA, Buckingham B, Waldeck N, Kershnar A, Gupta S (1984) Monoclonal antibody (Leu 7) defined NK cells in newly diagnosed insulin-dependent diabetes mellitus. Immunol Lett 8: 89-91

11. Gupta S, Charles MA, Waldeck N, Kershnar A, Buckingham B (1986) Multiparameter immunologic studies in patients with newly diagnosed type 1 insulin-dependent diabetes mellitus. Diabetes Res (in press)

12. Herold K, Huen A, Traisman H, Karrison T, Ruberstein A (1984) T lymphocyte subpopulations in type 1 diabetes mellitus: reduction in Leu 3 a (helper) population in new onset disease. Immunology in Diabetes '84, International Symposium, Rome, Italy 53

13. Abo Toru, Roder JC, Abo W, Cooper MD, Blach CM (1982) Natural killer $(\mathrm{HNK}-1+)$ cells in Chediak-Higashi patients are present in normal numbers but are abnormal in function and morphology. J Clin Invest 70: 193-197

14. National Diabetes Group (1979) Classification and diagnosis of diabetes mellitus and other categories of glucose intolerance. Diabetes $28: 1039-1057$

15. Fernandes G, Gupta S (1981) Killing and antibody-dependent cytotoxicity by lymphocyte subpopulations in young and aging humans. J Clin Immunol 1: 141-148

16. Boyum A (1976) Isolation of lymphocytes, granulocytes and macrophages. Scan J Immunol 5: 9-15

17. Falkoff RM, Peters M, Fauci AS (1982) T cell enrichment and depletion of human peripheral blood mononuclear cell preparations. Unexpected findings in the study of the functional activities of the separated populations. J Immunol Methods 50:39-49

18. Andersson LC, Jokinen M, Gahmberg CG (1979) Induction of erythroid differentiation in the human leukemia cell line K562. Nature 278: 364-365

19. Charles MA, Lawecki J, Pictet R, Grodsky GM (1975) Insulin secretion: interrelationship of glucose, cyclic adenosine 3', 5'-monophosphate, and calcium. J Biol Chem 250: 6134-6140

20. Timonen T, Saksela E (1980) Isolation of human NK cells by density gradient centrifugation. J Immunol Methods 36: 285-291

21. Salimonu LS, Ojo-Amaize E, Johnson AOK, Laditan AAO, Akinwolere OAO, Wigzell H (1983) Depressed natural killer cell activity in children with protein-calorie malnutrition. II. Correction of the impaired activity after nutritional recovery. Cell Immunol 82: 210-215

22. Roder JC, Pross HF (1982) The biology of the human natural killer cell. J Clin Immunol 2: 249-263

23. Zier KS, Spielman R, Baker L (1983) Decreased synthesis of IL-2 by insulin dependent diabetes. Human Immunol 8: 275

24. Lattime EC, Pecoraro GA, Stutman O (1983) The activity of natural cytotoxic cells is augmented by interleukin-2 and interleukin-3. J Exp Med 157: 1070-1075

25. Bankhurst AD (1982) The modulation of human natural cytotoxicity by prostaglandins. $\mathbf{J}$ Clin Lab Immunol 7: 85-91

26. Colwell JA, Halushka PV, Sarji KE (1978) Platelet function and diabetes mellitus. Med Clin North Am 62: 753-767

27. Irvine WJ, DiMario U, Guy K, Feek CM, Gray RS, Duncan LJP (1980) Immune complexes in newly diagnosed insulin-dependent (Type 1) diabetes. In: Irvine WU (ed) Immunolgy of diabetes. Teviot, Edinburgh, pp 219-227

Received: 23 July 1985

and in revised form: 10 March 1986

Dr. M. Arthur Charles

Rm C240, Medical Sciences I

Department of Medicine

University of California, Irvine

Irvine, CA 92717

USA 